\title{
กีĩm
}

Surnal \&konomi \& Q Keuangan @slam

Vol 8 No 1: Januari 2021 46-6o

https://journal.trunojoyo.ac.id/dinar/index

ISSN: 2460-9889 (Cetak)

DOI: https://doi.org/10.21107/dinar.v8i1.8939

ISSN: 2580-3565 (Online)

\section{MAPPING MUSLIM BEHAVIORS THROUGH ATTITUDES AND INTENTIONS IN CHOOSING CASH WAQF FOR ECONOMIC INDEPENDENCE}

\author{
Sri Hermuningsih ${ }^{1}$, Kusuma Chandra Kirana ${ }^{2}$, Retno Widiastuti ${ }^{3}$ \\ Fakultas Ekonomi Universitas Sarjanawiyata Tamansiswa Yogyakarta ${ }^{1,2}$, \\ Fakultas Tehnik Universitas Sarjanawiyata Tamansiswa Yogyakarta ${ }^{3}$ \\ hermun-feust@yahoo.co.id ${ }^{1}$, chandrakna@gmail.com², dias.rw@gmail.com ${ }^{3}$
}

\begin{abstract}
This research aims to analyze the factors of Wakif's motive in choosing cash waqf in Bantul Regency, Yogyakarta. This study was conducted quantitatively and used Ajzen's Theory of Planned Behavior. Subjective Norms, Government Support, and Self Efficacy on the attitude and intention of the choice to pay cash waqf were the variables in this research.

The objects of this study are those who pay the waqf that involves 98 respondents incorporated in Bazwa. The respondents were divided into four districts consist of 35 respondents from Banguntapan, 23 respondents from Bantul City, 11 respondents from Dlingo, and 29 respondents from Kasihan. Data were collected in two types of primary and secondary data. This study used a validity test, reliability test, and path analysis as the data analysis method.

The results of this study indicate the factors that influence wakif's motive in choosing cash waqf are subjective norms, Government Support, and Self Efficacy. Subjective norms had a significant positive effect on the motive through attitude. Self-efficacy is significant for attitude and insignificant for the motive. In contrast, Government support is not significant for attitude and motive, while attitude is significant for the motive.
\end{abstract}

Keywords: Attitude, Intention, Wakif, Cash Waqh

\section{INTRODUCTION}

Poverty with an inadequate level of education experienced by most of the Indonesian population has resulted in a portion of the Indonesian population living in the poverty line. This phenomenon is heartbreaking for Indonesian citizens, especially to the Government. Numerous attempts to alleviate poverty in Indonesia have been carried out by the Government, which resulted in the state budget increasing every year. However, these ways have not been conducted effectively. The ineffectiveness of poverty alleviation programs can be proven by Indonesia's economic growth of only 5\% (World Bank, 2016). This percentage is relatively small compared to neighboring countries such as Malaysia. In fact, we knew that 
Indonesia's natural and cultural wealth are similar or even better than other countries where the majority of the population are Moslems.

In an effort to encourage an independent economy, the government conducted a study aimed at exploring the potential for funding to help the nation's economic independence. Based on the previous researches, it was found that Indonesia is a country with the largest Muslim population in the world, which has tremendous potential from raising cash waqf funds. Nowadays, waqf is only known as a form of donation from those who can afford it to the community, which the allocation is used for socio-religious activities. Besides, from the view of muamalah fiqh, there is an unlimited cash waqf for the construction of mosques, Islamic boarding schools, and grave lands, which is allocated for the benefit of the people in terms of helping the community's economic independence.

Bantul Regency was chosen as the sample of this study because it belongs to the territory of Yogyakarta, where the majority of the population is Muslim. Based on data from the Central Bureau of Statistics, the Muslim population in Bantul is $95 \%$ of the total population of the region. With the majority of Muslim population, Bantul seemed to be able to apply the concept of the economic sovereignty of the ummah. The Nation's economic sovereignty is a form of kinship and mutual cooperation between community members in eradicating the poverty (Swasono, 2015). One of the functions of an Islamic economy is to eradicate poverty, where people who have excess sustenance help those in need. Indeed, this concept is also in line with the culture of the Indonesian society and reflects the meaning of article 2 Pancasila which is the fundamental of the National principle of Indonesia.

The lack of understanding among Indonesians towards the meaning of precepts in Pancasila and Islam is one of the factors that Indonesia has been crowned as a country with the largest Muslim population. Pancasila as a basic principle of Indonesia claims to protect the society's lives. Ironically, economic inequality still becomes an unsolved chronic problem thus far. Economic inequality in question also occurs in Bantul Regency. Based on data from BPS Special Region of Yogyakarta (DIY), Bantul Regency is classified as one of the districts with a high level of economic inequality. The following data is the distribution of the poverty rate in Yogyakarta:

Table 1

Number of Poor Population and Poverty Rate in Special Region of Yogyakarta in 2017

\begin{tabular}{lccl}
\hline Regency & Population (000) & Poverty Rate (\%) & $\begin{array}{l}\text { Poverty Line } \\
\text { Rp/Kap/Bln }\end{array}$ \\
\hline Bantul & 139,67 & 14,07 & 447.476 \\
Sleman & 96,75 & 8,13 & 351.331 \\
\hline
\end{tabular}




\begin{tabular}{lccc}
\hline Gunung Kidul & 135,74 & 18,65 & 277.261 \\
Kulon progo & 84,17 & 20,03 & 312.403 \\
Kota Yogyakarta & 32,2 & 7,64 & 423.815 \\
& & & \\
\hline Total & 488,53 & 13.02 & 488,53 \\
\hline
\end{tabular}

Source: BPS DIY

Based on the table above, it can be seen that Bantul Regency is one of the districts with the highest number of poor populations in DIY. Interestingly, contrary to this data, Bantul achieved the monthly average expenditure for each family with the highest consumption rate. If this condition related to the total Muslim population in Bantul Regency, then it is important to analyze the total expenditure allocation for socio-religious purposes in Bantul. (Zakat, Infaq, Sodaqoh and waqf). By knowing the amount of social expenditures, it is also expected to know the potential allocation of bylaws, especially for cash waqf .

Waqf is one of Islamic economic instruments that bases its function on the elements of virtue (birr), kindness (ibsan) and fraternity (ukhuwah) (Umrotul Khasanah, 2016). Indonesia's society recognizes waqf in the form of land or other immovable objects, which the utilization is limited to the construction of mosques, orphanages, and Islamic boarding schools . Cash waqf is increasingly known along with plenty of studies on Islamic economics, both over the world and in Indonesia in particular. Additionally, cash waqf is a type of waqf that is paid both before and after with the donation agreement. The main characteristic of cash waqf is when the waqf is paid, there is a shift in personal ownership towards the ownership of Allah SWT, which is expected to provide lasting benefits. It is expected that a process of distributing private benefits will occur towards social benefits through waqf.

The regulations regarding cash waqf are regulated based on the fatwa of the Indonesian Ulema Council which allows cash waqf (cash waqf/waqf al nuqud) on the condition that the principal value of the waqf must be guaranteed for its sustainability. In Law Number 41 of 2004 concerning waqf articles 28 - 31 and Government Regulation Number 42 of 2006 concerning its implementation (Law Number 41 of 2004 concerning Waqf) articles 22 - 27 explicitly state the permissibility of the implementation of cash waqf. In Bantul regency, the population of Muslims is 95\% (BPS DIY, 2017). This can be a great potential for cash waqf collection, considering that compared to other districts in Yogyakarta, Bantul is relatively low in poverty. If cash waqf can be implemented, then there are potential funds that can be used for the empowerment and welfare of the society . Research on cash waqf for the economy in the community has also been studied by several researchers but still finds differences in results. Based on research conducted by Umrotul Khazanah (2016) waqf as a source of productive economic empowerment for Muslims. While research conducted by Mokthar (2016) the factors that influence the intention of cash waqf are religiosity, generosity, knowledge of cash waqf, financial situation, recommendations (subjective norms) and service. Seeing that there are still differences in the results of research from previous researchers and considering the importance of cash waqf for economic independence in the community, especially Bantul district and to help local governments alleviate poverty which is still a chronic disease. In this regard, the 
researchers are interested in raising the research topic entitled Map of Muslim Behavior through Attitudes and Intentions to Choose Cash Waqf for Economic Independence.

\section{LITERATURE REVIEW}

\section{Definition of Poverty}

Epistemologically, poverty is a condition in which individuals do not have the economic ability to meet their needs. During this time, the common method used to calculate the number of poor people is the Head Count Index (HDI) method. According to this method, individuals who are categorized as poor are those who are below a limit that known as the poverty line.

An individual is said to live a healthy life when they are able to meet a minimum of 2100 kilo calories of energy per day (BPS Standard). Based on the provisions of the Central Bureau of Statistics (BPS), the poverty limit for food is the value of the rupiah an individual spends to be able to meet the necessities of life at least $2100 \mathrm{kkl}$ per day, which is based on food consumption and marginal class population.

\section{Cash Waqf}

Based on Law No. 41 regarding Waqf, it mentions the existence of waqf for movable objects in the form of money. Waqf money can be carried out by wakif, the person who giving the waqf, with a written statement of intent and issued with a certificate by a sharia financial institution. The Sharia Financial Institution on behalf of Nazhir, the person in charge of management, registers waqf assets in the form of money with the Minister no more than 7 (seven) working days after the issuance of Cash Waqf.

\section{Economic Independence}

Economic independence is a situation where the community is able to meet economic needs independently through production activities in order to make themselves prosperous and independent from others. Therefore, the economic independence referred to in this study is the ability of former female workers (TKW) in Gunung Kidul to meet their economic needs independently without the domination of other parties.

Waqf as a Source of Productive Economic Empowerment (the Perspective of the Benefits of Waqf Based on the Islamic Financial System)

This study was conducted by Umrotul Khasanah. The researcher stated that waqf is a source of Islamic wealth that is utilized to finance the struggle of Muslims. One of struggles in Islam is eradicating poverty. Therefore, waqf can be used as a means of struggle because the legal standing of waqf is sunnah, not mandatory, so it becomes more flexible and elastic in its use as an economic empowerment for the society, especially in poverty alleviation.

\section{Empowerment of the Poor Society in the Special Region of Yogyakarta}

This program initiated and carried out by the provincial government of the Special Region of Yogyakarta (DIY) started in 2010 until 2011. The purposes of this program are to improve the functions of facilities or infrastructure for community needs, improve the quality of households and sanitation for poor households, and empower the community actively, integrated and mutually, and sustainably. This program is able to build various public facilities 
and provide public awareness for healthy living. However, in its implementation, this program has not been able to empower the poor society in DIY to have economic independence.

\section{Poverty Empowerment Program}

The aim of the program designed by Bappenas is to encourage the realization of village community independence through developing superior potential and strengthening institutions and empowering community groups for Poor Households. Initially, this program was deemed effective in being able to find the superior potential of the region, but its implementation was not effective because not all societies participated in this program.

\section{Economic Independence}

A situation where society can meet their economic needs independently through production activities for their own welfare and do not depend on others. Therefore, the economic independence referred to in this study is the ability of individuals in Bantul to meet their economic needs independently without the domination of other parties.

\section{Theory of Planned Attitude}

Subjective norms are actions that are often based on individual's perceptions of what to do (Fishbein \& Ajzen, 2006). Meanwhile, the meaning of attitude is an individual's positive or negative feelings towards target behavior (Fishbein \& Ajzen, 2006). Intention means a person's subjective tendency to perform specific behaviors that build relationships between objects and attributes (Ajzen, 2009).

\section{Theory of Planned Behavior}

According to Fishbien (2006), behavioral intention (BI) of individuals to engage in behavior is determined by individual's attitudes and subjective norms, which are the overall perception of what other people think about what the individual should do. On the other hand, Ajzen (2005) states that humans are basically rational and make systematic use of the information available to them when making decisions. Taking into account the factors associated with control, Planetary Behavior Theory (TPB) assumes that learned behavior controls the progress of behavior so that it is directed toward a goal.

\section{GIS -Based Decision Support System for Cash Waqf Distribution}

Gunung Kidul Regency of Indonesia has a problem with a massive number or former migrant woman workers (MWW), who live in poverty. Meanwhile, Indonesian society who are Muslim in majority have a large potential to do cash waqf (a form of donation worship in Islam) The fund collected can be utilized for community empowerment, specifically former MWW to reach their financial independence. It needs a model to do cash waqf distribution so the fund can be right on target and by the needs of the community. A decision support system approach utilizing knowledge representation in an expert system is proposed in this research. The model built is implemented in the application with GIS-shape visualization. The model and applications have been tested and were accepted by potential users, but further development is still required to be implemented .

The Analysis of Entrepreneurial Intention Factors for Female Workers' Autonomy in Gunung Kidul

This study aims to analyze the influence of personality, environment, and demographics of full-time female workers in Gunug Kidul Yogyakarta. By knowing the influence of the 
variables studied, it can provide appropriate suggestions to help alleviate poverty in Gunung Kidul, Yogyakarta. This research is a quantitative study using a sampling method. Samples were taken from the subject population who were former female workers in Gunung Kidul Regency, Yogyakarta. Sources of data used in this study are primary data and secondary data which are complementary. The data collection technique is conducted by using questionnaires, interviews and documentation. The result of this study showed that there is a partial correlation of personality, environment, and demographic variables to the entrepreneurial intentions of fulltime female workers. Among the three variables, the environment has the strongest influence on intention, and simultaneously shows a correlation of personality, environmental, and demographic variables on the entrepreneurial intentions of full-time female workers in Gunung Kidul. The contribution of the three variables to the intention was $23.3 \%$, while the rest was influenced by other variables. Simultaneous hypothesis testing shows that the environmental variables, personality variables, and demographic variables have an effect on the entrepreneurial intentions of full-time female workers in Gunung Kidul.

\section{RESEARCH METHODOLOGY}

This study used both quantitative and qualitative methods by conducting survey and indepth interview as instruments to collect the data. Quantitative data collection used sampling methods in which the sample is taken from the population of existing research subjects. Sources of data used in this study are primary data, which is data taken directly from the field and secondary data which are complementary. This study using a descriptive-evaluative approach. According to Arikunto, descriptive research is not intended to test certain hypotheses, it's to describe variable, symptom, or phenomenon. Meanwhile, the evaluative approach is a process carried out to determine policies by developing thinking techniques for making decisions (Suharsimi Arikunto, 2010). The result of this study is expected to provide input for the government.

The subjects in this study were the Muslim population in Indonesia who were categorized as economically well off and classified as poor. The sampling using a combination of stratified sampling and random sampling. A random sampling is used to determine the poor in the areas to be studied. Based on the technique used, a number of " $n$ " samples will be determined from the entire existing community in Yogyakarta. After determining the number of " $\mathrm{n}$ " samples, the data will be determined randomly (stratified random), so that all poor subjects in the areas have the same probability level to be sampled.

\section{Research Location and Period}

The research is conducted in the Province of Special Region of Yogyakarta and spend 22 (twenty two) months for the whole study.

\section{Research Models}

The model in this study can be seen in Figure 1 below:

Based on this model, the hypotheses proposed in this study are:

H1: Subjective Norms have a positive effect on Attitude

H2: Subjective Norms have a positive effect on Intention

H3: Self-efficacy has a positive effect on Attitude 
H4: Self-efficacy has a positive effect on Intention

H5: Government Support has a positive effect on Attitude

H6: Government Support has a positive effect on Intention

H7: Attitude has a positive effect on Intention

\section{RESULT AND DISCUSSION}

\section{Evaluation of Model Fit}

\section{Outer Model Assessment or Measurement Model}

\section{Convergent validity}

This study uses a loading factor limit of 0.5 that meet the convergent validity if the loading factor value on each item is $>0.50$. The results of processing using SmartPLS can be seen in the following figure and table .

Figure 1

The results of processing using SmartPLS

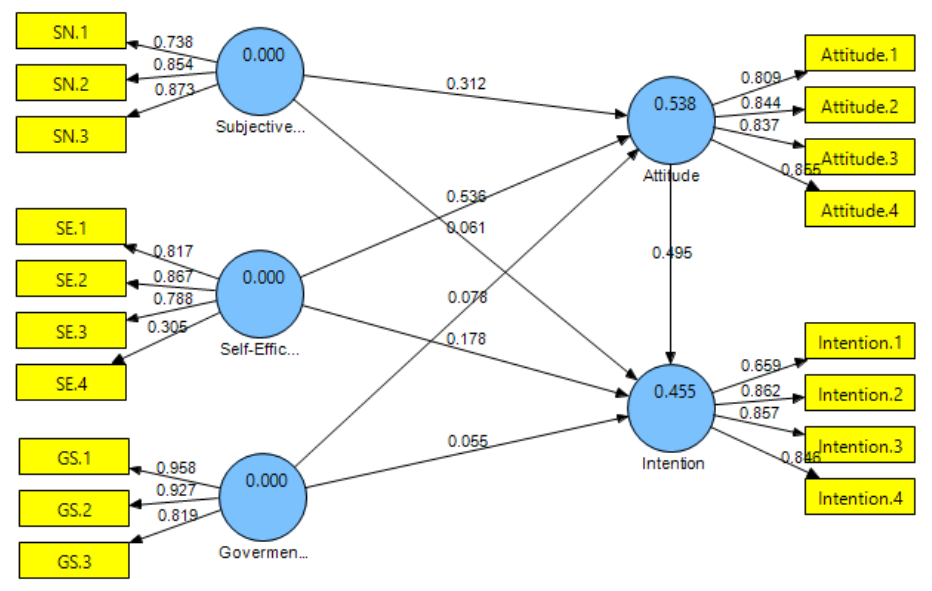

Table 2

Outer Loadings (Measurement Model)

\begin{tabular}{|c|c||c|c|c|c|}
\hline & Attitude & Goverment Support & Intention & Self-Efficacy & Subjective Norms \\
\hline Attitude.1 & 0.809413 & & & & \\
\hline Attitude.2 & 0.844291 & & & & \\
\hline Attitude.3 & 0.836603 & & & & \\
\hline Attitude.4 & 0.855433 & & & & \\
\hline GS.1 & & 0.958269 & & & \\
\hline GS.2 & & 0.926923 & & & \\
\hline GS.3 & & 0.818940 & & & \\
\hline Intention.1 & & & 0.658723 & & \\
\hline
\end{tabular}




\begin{tabular}{|c||c||c||c||c|c|}
\hline & Attitude & Goverment Support & Intention & Self-Efficacy & Subjective Norms \\
\hline Intention.2 & & & 0.861603 & & \\
\hline Intention.3 & & & 0.856664 & & \\
\hline Intention.4 & & & 0.845852 & & \\
\hline \hline SE.1 & & & & 0.817228 & \\
\hline SE.2 & & & & 0.867360 & \\
\hline \hline SE.3 & & & & 0.787549 & \\
\hline \hline SE.4 & & & & 0.305347 & \\
\hline \hline SN.1 & & & & & 0.737737 \\
\hline \hline SN.2 & & & & & 0.853730 \\
\hline \hline SN.3 & & & & & 0.872951 \\
\hline
\end{tabular}

Source: Processed research data

The results on table 2 indicate that there is 1 item in the Self-Efficacy variable which has a factor loading value $<0.05$, that is the SE. 4 item with a value of 0.305 . Because the factor loading value $<0.05$, it must be removed from the model. The results after item SE.4 are removed from the model can be seen in the following figure and table.

Figure 2

The results after item SE.4

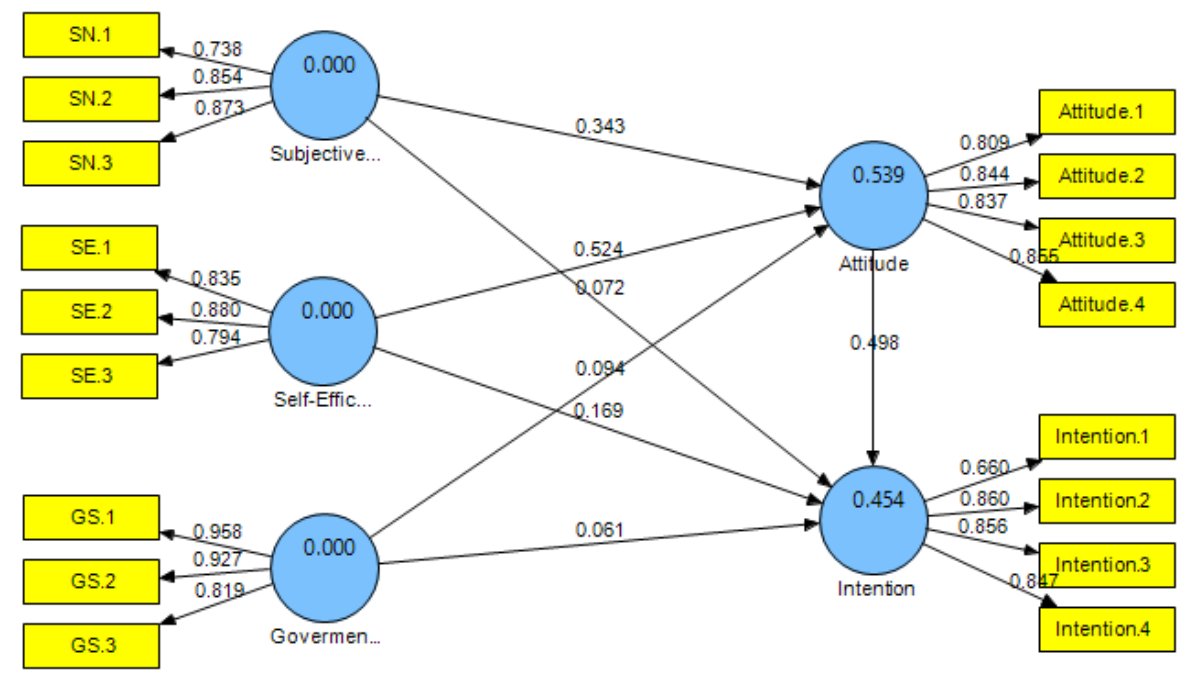

Table 3

Outer Loadings (Measurement Model)

\begin{tabular}{|l|l|l|l|l|l|}
\hline & Attitude & Goverment Support & Intention & Self-Efficacy & Subjective Norms \\
\hline \hline Attitude.1 & 0.809197 & & & & \\
\hline Attitude.2 & 0.844379 & & & & \\
\hline \hline
\end{tabular}




\begin{tabular}{|c|c|c|c||c|c|}
\hline & Attitude & Goverment Support & Intention & Self-Efficacy & Subjective Norms \\
\hline \hline Attitude.3 & 0.836852 & & & & \\
\hline Attitude.4 & 0.855376 & & & & \\
\hline GS.1 & & 0.958238 & & & \\
\hline GS.2 & & 0.926949 & & & \\
\hline GS.3 & & 0.818974 & & & \\
\hline Intention.1 & & & 0.660235 & & \\
\hline Intention.2 & & & 0.860412 & & \\
\hline Intention.3 & & & 0.855832 & & \\
\hline Intention.4 & & & 0.846775 & & \\
\hline SE.1 & & & & 0.835241 & \\
\hline SE.2 & & & & 0.879582 & \\
\hline SE.3 & & & & 0.794437 & \\
\hline \hline SN.1 & & & & & 0.737695 \\
\hline SN.2 & & & & & 0.853830 \\
\hline SN.3 & & & & & 0.872871 \\
\hline \hline
\end{tabular}

Source: Processed research data

The results above show that the outer model value or the correlation between the indicators and the variables in the study has met the convergent validity because all of them have a loading factor value above 0.50 .

\section{Discriminant Validity}

Discriminant validity testing is conducted to ensure that each concept of each latent variable is different from other variables. The model said to have good discriminant validity if each indicator loading value of a latent variable is more correlated with this latent variable than if it is correlated with other latent variables. The results of discriminant validity testing were obtained as follows :

\section{Table 4}

\section{Discriminant Validity Value (Cross Loading)}

\begin{tabular}{|c|c|c|c|c|c|c|}
\hline & Attitude & Government Support & Intention & Self-Efficacy & Subjective Norms \\
\hline \hline Attitude.1 & $\mathbf{0 . 8 0 9 1 9 7}$ & 0.254897 & 0.718251 & 0.596878 & 0.343435 \\
\hline \hline
\end{tabular}




\begin{tabular}{|c||c||c||c||c|c|}
\hline & Attitude & Government Support & Intention & Self-Efficacy & Subjective Norms \\
\hline Attitude. 2 & $\mathbf{0 . 8 4 4 3 7 9}$ & 0.070879 & 0.539774 & 0.548396 & 0.419983 \\
\hline \hline Attitude.3 & $\mathbf{0 . 8 3 6 8 5 2}$ & 0.108580 & 0.429003 & 0.451599 & 0.525269 \\
\hline \hline Attitude.4 & $\mathbf{0 . 8 5 5 3 7 6}$ & 0.118328 & 0.463631 & 0.570923 & 0.490245 \\
\hline \hline GS.1 & 0.193718 & $\mathbf{0 . 9 5 8 2 3 8}$ & 0.205235 & 0.151197 & 0.005921 \\
\hline \hline GS.2 & 0.163117 & $\mathbf{0 . 9 2 6 9 4 9}$ & 0.126547 & 0.112182 & 0.033821 \\
\hline \hline GS.3 & 0.050616 & $\mathbf{0 . 8 1 8 9 7 4}$ & 0.087046 & 0.063663 & 0.046098 \\
\hline Intention.1 & 0.353651 & 0.150367 & $\mathbf{0 . 6 6 0 2 3 5}$ & 0.307525 & 0.190410 \\
\hline Intention.2 & 0.527482 & 0.160387 & $\mathbf{0 . 8 6 0 4 1 2}$ & 0.398875 & 0.316515 \\
\hline Intention.3 & 0.575028 & 0.147197 & $\mathbf{0 . 8 5 5 8 3 2}$ & 0.503521 & 0.313570 \\
\hline Intention.4 & 0.622079 & 0.110409 & $\mathbf{0 . 8 4 6 7 7 5}$ & 0.467735 & 0.412183 \\
\hline \hline SE.1 & 0.596159 & 0.108188 & 0.509231 & $\mathbf{0 . 8 3 5 2 4 1}$ & 0.282701 \\
\hline \hline SE.2 & 0.585113 & 0.202590 & 0.461884 & $\mathbf{0 . 8 7 9 5 8 2}$ & 0.312095 \\
\hline \hline SE.3 & 0.434532 & -0.008114 & 0.321751 & $\mathbf{0 . 7 9 4 4 3 7}$ & 0.263864 \\
\hline \hline SN.1 & 0.252447 & 0.009513 & 0.169381 & 0.170163 & $\mathbf{0 . 7 3 7 6 9 5}$ \\
\hline \hline SN.2 & 0.466911 & 0.124980 & 0.404227 & 0.321989 & $\mathbf{0 . 8 5 3 8 3 0}$ \\
\hline SN.3 & 0.506376 & -0.080890 & 0.332546 & 0.311479 & $\mathbf{0 . 8 7 2 8 7 1}$ \\
\hline \hline PrOcess & & & & \\
\hline
\end{tabular}

Source: Processed research data

According to table 3, it can be seen that the loading factor value for each indicator of each latent variable has the largest loading factor value, compared to the loading factor value when associated with other latent variables. This means that each latent variable has good discriminant validity.

\section{Composite Reliability dan Average Variance Extracted (AVE)}

Validity and reliability criteria can also be seen from the Composite Reliability and the Average Variance Extracted (AVE) value of each construct. The construct is said to have high reliability if the composite reliability value is above 0.70 and AVE is above 0.50 .

\section{Table 5}

Composite Reliability and Average Variance Extracted (AVE)

\begin{tabular}{|c||c|c|}
\hline & Composite Reliability & Average Variance Extracted(AVE) \\
\hline \hline Attitude & 0.903165 & 0.699941 \\
\hline Goverment Support & 0.929832 & 0.816058 \\
\hline \hline Intention & 0.883174 & 0.656424 \\
\hline \hline Self-Efficacy & 0.875232 & 0.700807 \\
\hline Subjective Norms & 0.862907 & 0.678374 \\
\hline
\end{tabular}

Source: Processed research data 
Table 4 showed that all constructs meet composite reliability because their values are in the range $0.863-0.930$. Similarly, the resulting AVE value is in accordance with the recommended value, which is more than 0.5 . Another way to test discriminant validity is to compare the AVE square root value of each construct with the correlation between constructs.

Table 6

\section{Latent Variable Correlations \& AVE Square Root}

\begin{tabular}{|c||c||c|c||c|c|}
\hline & Attitude & Government Support & Intention & Self-Efficacy & Subjective Norms \\
\hline \hline Attitude & $\mathbf{0 . 8 3 6 6 2 5}$ & & & & \\
\hline \hline Government Support & 0.172242 & $\mathbf{0 . 9 0 3 3 5 9}$ & & & \\
\hline \hline Intention & 0.656387 & 0.170940 & $\mathbf{0 . 8 1 0 2 0 0}$ & & \\
\hline Self-Efficacy & 0.654308 & 0.133043 & 0.527305 & $\mathbf{0 . 8 3 7 1 4 2}$ & \\
\hline Subjective Norms & 0.524723 & 0.024234 & 0.392502 & 0.343070 & $\mathbf{0 . 8 2 3 6 3 5}$ \\
\hline \hline
\end{tabular}

Source: Processed research data

According to table 5, it can be seen that the square root value of AVE (diagonal number in the table) is higher than the correlation between one construct and another, so that each construct fulfills good discriminant validity.

\section{Structural Model Testing (Inner Model)}

Figure 3

\section{Structural Model}

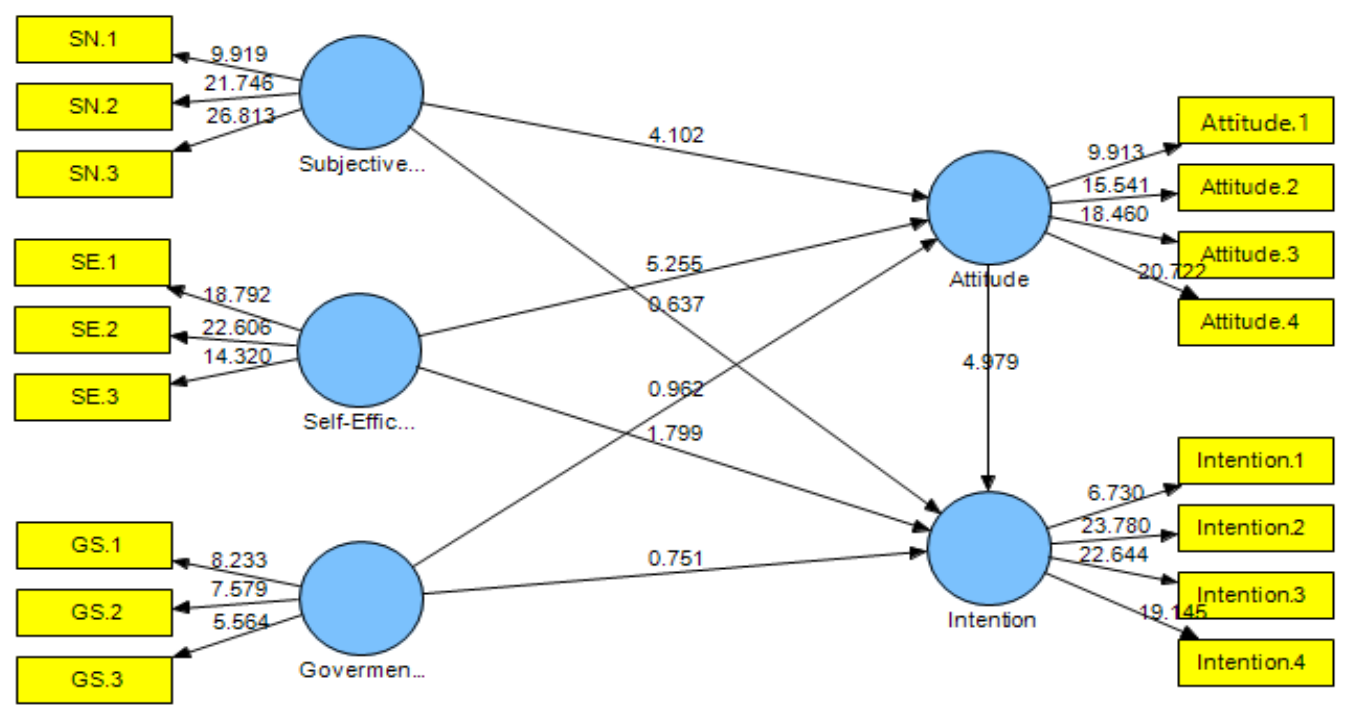

Table 7

R-Square Value

\begin{tabular}{|c|c|}
\hline & R Square \\
\hline \hline Attitude & 0.539005 \\
\hline
\end{tabular}




\begin{tabular}{|c||c|}
\hline Government Support & \\
\hline \hline Intention & 0.454361 \\
\hline Self-Efficacy & \\
\hline \hline Subjective Norms & \\
\hline
\end{tabular}

Source: Processed research data

Based on the table above, it shows that the $\mathrm{R}$-square value for the Attitude variable is 0.539. This means that the variable Attitude is explained by the Subjective Norms, Self-Efficacy and Government Support variables by 53.9\%. While the R-square value for the Intention variable is 0.454, which means that the Intention variable is explained by the Subjective Norms, Self-Efficacy, Government Support and Attitude variables of $45.4 \%$.

Evaluation of the construct model is carried out by calculating the predictive relevance Q-square as follows:

$$
\begin{aligned}
\mathrm{Q}^{2} & =1-\left(1-\mathrm{R}_{\text {Attitude }^{2}}\right)\left(1-\mathrm{R}_{\text {Intension }^{2}}\right) \\
& =1-(1-0,539)(1-0,454) \\
& =1-(0,461)(0,546) \\
& =1-0,252 \\
& =0,748
\end{aligned}
$$

Based on the calculation above, the Q2 value obtained is 0.748 , which indicates that the model is well formed.

\section{Hypotheses Testing}

To test the proposed hypothesis, it can refer to the t-statistic value. If the t statistical value $>\mathrm{t}$ table, then the hypothesis will be accepted. The $\mathrm{t}$-statistical estimation results can be seen in the results for inner weight, which are presented in the following table .

\section{Table 8}

\section{Path Coefficients (Mean, STDEV, T-Values)}

\begin{tabular}{|c||c||c||c||c||c|}
\hline \hline & $\begin{array}{c}\text { Original } \\
\text { Sample } \\
\mathbf{( O )}\end{array}$ & $\begin{array}{c}\text { Sample } \\
\text { Mean } \\
(\mathbf{M})\end{array}$ & $\begin{array}{c}\text { Standard } \\
\text { Deviation } \\
\text { (STDEV) }\end{array}$ & $\begin{array}{c}\text { Standard } \\
\text { Error } \\
\text { (STERR) }\end{array}$ & $\begin{array}{c}\text { T Statistics } \\
\text { (|O/STERR } \\
\text { I) }\end{array}$ \\
\hline \hline Attitude -> Intention & 0.497581 & 0.487773 & 0.099933 & 0.099933 & 4.979129 \\
\hline \hline Government Support -> Attitude & 0.094193 & 0.080296 & 0.097910 & 0.097910 & 0.962032 \\
\hline \hline Government Support -> Intention & 0.061018 & 0.058355 & 0.081259 & 0.081259 & 0.750899 \\
\hline \hline Self-Efficacy -> Attitude & 0.524244 & 0.521842 & 0.099765 & 0.099765 & 5.254807 \\
\hline \hline Self-Efficacy -> Intention & 0.168922 & 0.158957 & 0.093897 & 0.093897 & 1.799024 \\
\hline \hline Subjective Norms -> Attitude & 0.342588 & 0.345856 & 0.083511 & 0.083511 & 4.102296 \\
\hline \hline Subjective Norms -> Intention & 0.071979 & 0.093962 & 0.112931 & 0.112931 & 0.637371 \\
\hline \hline
\end{tabular}

Source: Processed research data

According to table 8 , the research hypothesis can be tested. Hypothesis testing uses a significance level of 5\% with t table of $1.985(\mathrm{~N}=96)$.

H1: Subjective Norms have a positive effect on Attitude 
The result of the parameter coefficient test between Subjective Norms and Attitude shows a coefficient value of 0.343 and a calculated $t$ value of 4.102 . At the significance level $(\alpha)=0.05$, the $t$ value is greater than the $t$ table value of 1.985. This shows that Subjective Norms have a positive effect on Attitude .

H2: Subjective Norms have a positive effect on Intention

The result of the parameter coefficient test between Subjective Norms and Intention shows a coefficient value of 0.072 and a calculated t value of 0.637 . At the significance level $(\alpha)=0.05$, the $t$ value is lower than the $t$ table value of 1.985. This shows that Subjective Norms did not affect Intention .

H3: Self-Efficacy has a positive effect on Attitude

The result of the parameter coefficient test between Self-Efficacy and Attitude shows the coefficient value of 0.524 and the $t$ value of 5.255. At the significance level $(\alpha)=0.05$, the $t$ value is greater than the $t$ table value of 1.985 . This shows that Self-Efficacy is positively affect Attitude .

\section{H4: Self-efficacy has a positive effect on Intention}

The result of the parameter coefficient test between Self-Efficacy and Intention shows the coefficient value of 0.169 and the $t$ value of 1.799. At the significance level $(\alpha)=0.05$, the $t$ value is lower than the t table value of 1.985. This shows that Self-Efficacy has no effect on Intention

\section{H5: Government Support has a positive effect on Attitude}

The result of the parameter coefficient test between Government Support and Attitude shows a coefficient value of 0.094 and a calculated $t$ value of 0.962 . At the significance level $(\alpha)=$ 0.05 , the $\mathrm{t}$ value is lower than the $\mathrm{t}$ table value of 1.985. This shows that Government Support did not affect Attitude.

H6: Government Support has a positive effect on Intention

The result of the parameter coefficient test between Government Support and Intention shows the coefficient value of 0.061 and the $t$ value of 0.751 . At the significance level $(\alpha)=0.05$, the $\mathrm{t}$ value is lower than the $\mathrm{t}$ table value of 1.985. This shows that Government Support has no effect on Intention

H7: Attitude has a positive effect on Intention

The result of the parameter coefficient test between Attitude and Intention shows a coefficient value of 0.498 and a calculated $t$ value of 4.979. At the significance level $(\alpha)=0.05$, the $\mathrm{t}$ value is greater than the $\mathrm{t}$ table value of 1.985 . This shows that Attitude positively affect the Intention.

\section{CONCLUSIONS}

Based on the results of data analysis, the conclusions can be drawn as follows: First, the result of the parameter coefficient test between Subjective Norms and Attitude showsna coefficient value of 0.343 and a calculated t value of 4.102. At the significance level $(\alpha)=0.05$, the $t$ value is greater than the $t$ table value of 1.985. This shows that Subjective Norms have a positive effect on Attitude.

Second, The result of the parameter coefficient test between Subjective Norms and Intentionshows a coefficient value of 0.072 and a calculated $t$ value of 0.637 . At the significance 
level $(\alpha)=0.05$, the t value is lower than the t table value of 1.985 . This shows that Subjective Norms did not affect Intention.

Third, the result of the parameter coefficient test between Self-Efficacy and Attitude shows the coefficient value of 0.524 and the $t$ value of 5.255. At the significance level $(\alpha)=$ 0.05 , the $\mathrm{t}$ value is greater than the $\mathrm{t}$ table value of 1.985 . This shows that Self-Efficacy is positively affect Attitude .

Fourth, the result of the parameter coefficient test between Self-Efficacy and Intention shows the coefficient value of 0.169 and the $t$ value of 1.799 . At the significance level $(\alpha)=$ 0.05 , the $\mathrm{t}$ value is lower than the $\mathrm{t}$ table value of 1.985 . This shows that Self-Efficacy has no effect on Intentioni?".

Fifth, the result of the parameter coefficient test between Government Support and Attitude shows a coefficient value of 0.094 and a calculated $t$ value of 0.962 . At the significance level $(\alpha)=0.05$, the $t$ value is lower than the t table value of 1.985. This shows that Government Support did not affect Attitude".

Sixth, the result of the parameter coefficient test between Government Support and Intention shows the coefficient value of 0.061 and the $t$ value of 0.751 . At the significance level $(\alpha)=0.05$, the $t$ value is lower than the $t$ table value of 1.985 . This shows that Government Support has no effect on Intention".

Seventh, the result of the parameter coefficient test between Attitude and Intention shows a coefficient value of 0.498 and a calculated $t$ value of 4.979. At the significance level $(\alpha)=0.05$, the $\mathrm{t}$ value is greater than the $\mathrm{t}$ table value of 1.985 . This shows that Attitude positively affect the Intention".

Eighth, the potential for cash waqf in Bantul is inflated, but the socialization is still lacking. Therefore, only several Muslims in Bantul know about cash waqf.

Ninth, the attitude of Muslims in Bantul towards the choice of cash waqf influenced by subjective norms and self-efficacy and the intention of Muslims in Bantul is influenced by selfefficacy and attitude towards cash waqf. Meanwhile, Government support does not affect the attitudes and intentions of Muslims in Bantul to do the cash waqf.

\section{REFERENCES}

Aedy, H. Hasan, 2005. Peranan Pemerintah dan Ulama dalam Pengelolaan Pajak, Zakat dan Wakaf untuk Penanggulangan Kemiskinan dan Peningkatan Ekonomi Umat. Proceeding of International Seminar On Islamic Economics As A Solution, IAEI Medan 18-19 September.

Al-Arif, Potensi Wakaf Tunai Serta Dampaknya Terhadap Perekonomian, http://www.academia.edu

Alisuddin, 2002. Zakat atas Tabungan. Mon Mata, Jurnal Ilmu-ilmu Ssial Bidang Ekonomi. Vol 4 No. 2 Desember 2002. Hal $89-100$

Amalia Euis 2009, Keadilan Distributif Dalam Ekonomi, Jakarta, PT. Raja Grafindo Persada Amani, farouk \& Abbes Ikram. 2014. The Influence of Individual Factors The Entrepreneurial Intention. 2014. International Journal of Managing Value and Supply Chains (IJMVSC) Vol. 5 No. 4 Desember. Pp. $47-57$.

Arikunto, Suharsimi.2006. Prosedur Penelitian Suatu Pendekatan Praktek. Jakarta: PT Renika Cipta. 
Azjen,I. \& Fishbein,M (2005). The Influence of Attitudes on Behavior. In D. Albarrcin, B.T. Johnson \& M.P. Zanna (Eds). The handbook of attitudes (pp.173-221) Mahwah, NJ : Erlbaum.

Bapeda Gunung Kidul, Program Pemberdayaan Ekonomi Masyarakat, 2014

Chamid, Nur. 2009. Membangun Masyarakat Madani : Upaya Mendukung Pemberdayaan Basic Sistem Ekonomi Islam Menurut Ibnu Khaldun Economic Model. Jurnal Empirisima. Vol 18. No. 1 Januari 2009. Hal $101-112$

Fanani, Muhyar. 2011. Pengelolaan wakaf Tunai. Walisongo Jurnal Penelitian Sosial keagamaan. Vol. 19 No. 1.

Farhah binti Saefudin, et.all. 2014. The Role of Cash Waqf in Poverty Alleviation : Case of Malaysia. International Journal of Business, Economics and Law. Vol. 4 Issue 1(June) . pp.171179.

Fitria Utami, Anisa. Munawar Ismail. 2016. Implementasi pengelolaan wakaf Tunai (Studi Pada Baitul Maal Hidayatullah \& Yayasan Dana Sosial al-Falah). Jurnal Ilmiah Mahasiswa FEB Universitas Brawijaya. Vol. 3 No. 1 Semester Ganjil 2014/2015.

Gamal, Merza, 2006, Sedekah Dalam Perspektif Pemberdayaan Ekonomi Umat, Ekonomi Nasional, Edisi Selasa 12 Oktober.

Hasan, Sami, 2006, Muslim Philanttrhropy and Sosial security : Prospects, Practices, and Fitfalls, http// wnw.istr, org/conferences/Bangkok/WPV Volume.

Khasanah, Umrotul, Waqf a Source of Productive Economic Empowerment (Perspective on Waqf Benefits Based on Islamic Financial System)

Kusrini, Kusuma Chandra Kirana, Idris Purwanto and Arief Laksito, 2018. GIS-Based Decision Support System For Cash Waqh Distribution . Journal of Theoretical and Applied Information Technology. Vol 96 , no. 3. Issue 15 (February) pp 71-77.

Kusuma Chandra Kirana,dkk, 2017. Analisis Faktor Intensi Kewirausahaan Tenaga Kerja Wanita Purna Gunung Kidul Untuk Kemandirian. Jurnal Ekuitas Stesia, Vol 1 No 3 hal. 303.

Mokthar, M. Z. (2016). Perceptions of Universiti Sains Malaysia Muslim Staff on Factors Influencing Their Intention to Perform Cash Waqf. Journal of Islamic Studies and Culture, Vol. 4, No. 2, e-ISSN 2333- 5912, 101-109.

Sudirman, 2005. Pengembangan Wakaf Tunai untuk keadilan social. Resipetory.uin-malang.ac.id 